\title{
GAME EDUKASI BAGI ANAK AUTIS BERTEMA ANGGOTA KELUARGA BERBASIS KINECT XBOX 360
}

\author{
Fatah Yasin Al Irsyadi \\ Fakultas Komunikasi dan Informatika, Program Studi Informatika \\ Universitas Muhammadiyah Surakarta \\ Email: fatah.yasin@ums.ac.id \\ Arini Nur Rohmah \\ Fakultas Komunikasi dan Informatika, Program Studi Informatika \\ Universitas Muhammadiyah Surakarta \\ Email: arininrohmah@gmail.com
}

\begin{abstract}
ABSTRAK
Pengenalan obyek merupakan salah satu materi pembelajaran yang masuk dalam kurikulum pembelajaran anak autis tingkat sekolah dasar di sekolah terpadu Rumah Pintar Salatiga. Selama ini pengenalan obyek dilakukan dengan cara guru menyiapkan gambar obyek seperti yang terdapat dalam buku panduan kemudian ditunjukkan pada siswa. Metode seperti ini selain kurang menarik, memungkinkan siswa autis mengalami kesulitan untuk mengenali obyek, aktifitas gerak motorik mereka kurang dan akan cepat merasa bosan. Hal ini sesuai dengan karakter anak autis. Penelitian ini bertujuan untuk memperkenalkan obyek anggota keluarga yaitu meliputi ibu, bapak, adik dan kakak serta beberapa obyek benda sesuai kurikulum di sekitar keluarga. Pengenalan obyek dikemas dalam sebuah game edukasi yang berbasis kinect xbox 360, sehingga menarik dan interaktif sekaligus melatih gerak motorik para siswa. Wawancara terhadap para guru dilakukan untuk mengetahui metode pembelajaran pengenalan obyek, metode melatih gerak motorik, mengetahui tingkat kemampuan berkomunikasi dan menangkap informasi dari anak autis. Game ini dibuat menggunakan software utama Kinect SDK dan Unity 2D/3D. Aset-aset obyek dalam game ini dibuat menggunakan software inkscape dan animasinya menggunakan software dragonbones. Pengujian dilakukan dengan mendemokan game edukasi ini kepada para siswa kemudian mereka diberi kesempatan untuk mencoba sambil didampingi beberapa guru pengajar. Kuisioner yang diisi oleh para guru menyatakan bahwa game ini dapat digunakan untuk merehabilitasi gerak motorik anak autis, mudah dimainkan, sangat menarik dan dapat digunakan sebagai salah satu alat bantu pembelajaran bagi anak autis tingkat sekolah dasar.
\end{abstract}

Kata kunci: autis, game edukasi, kinect xbox, motorik.

\begin{abstract}
Objects introduction is one of learning materials included in learning competence curriculum for primary level autistic children used in integrated school of Rumah Pintar Salatiga. During this time, objects introduction done with teacher preparing the object image as contained in the guidebook and then shown to the students. Such methods are less interesting, allowing autistic students to have difficulty in recognizing objects, their motor activity is insufficient and will quickly get bored. This corresponds to the character of an autistic child. This study aims to introduce family members object in a small scope includes father, mother, brother and sister as well as some objects around according to the curriculum. The introduction of an object is packaged in an educational game based on kinect xbox 360, so it is interesting and interactive as well as train the students' motor movements. Interview of teachers was done to know the method of learning object recognition, motor movement training method, knowing the level of ability to communicate and capture information from children with autism. This game made by using main software Unity 2D / 3D and Kinect SDK. Object assets of this game using Inkscape software while DragonBones software for the animation. Testing is done by demonstrating this educational game to the students, then they are given the opportunity to try accompanied by several teachers. The questionnaire's result filled by teachers stated that the game is easy to play, very interesting and enable to rehabilitate autistic child's motor movement, as well as one learning media for autism child in primary school.
\end{abstract}

Keywords: autism, education game, kinect xbox, motoric. 


\section{PENDAHULUAN}

American Psychiatric Association, menyatakan bahwa autis merupakan gangguan perkembangan syaraf yang kompleks pada otak anak, dan biasanya terjadi pada anak usia dini. Tanda-tanda gangguan autisme adalah adanya kesulitan atau beberapa taraf keterlambatan dalam berinteraksi social, komunikasi secara nonverbal maupun verbal dan tingkah laku yang diulang-ulang pada suatu keminatan atau atau aktivitas [2].

Sekolah terpadu Rumah Pintar Salatiga merupakan lembaga pendidikan untuk Anak Berkebutuhan Khusus (ABK) .tunagrahita dan autis. Salah satu tujuan dari sekolah ini adalah mendidik anak berkebutuhan khusus autis dengan berbagai bidang ilmu untuk menggali kemampuan anak didik secara optimal. Kurikulum yang digunakan di sekolah ini bersifat tematik dan berbasis kompetensi untuk anak autis tingkat sekolah dasar. Tema keluarga merupakan salah satu tema yang diajarkan. Pada tema ini anak-anak autis dituntut untuk mampu mengenali lingkup kecil anggota keluarga, yaitu ibu, bapak, adik dan kakak. Selain itu, mereka juga dituntut mengenali benda-benda di lingkungan keluarga seperti kursi, meja, penggaris, buku, piring, gelas dan lain-lain. Materi menulis, bersikap baik dan berhitung juga diajarkan pada tema keluarga.

Karakteristik anak autis umumnya adalah susah untuk fokus, cepat merasa bosan apabila disodori hal-hal yang tidak sesuai dengan keminatan, dan kurang mampu mengontrol gerak motorik mereka. Peran guru pembimbing sangat diharapkan untuk mengajarkan materi dengan kreatif, baik dan menyenangkan. Selain itu, harus mampu membimbing anak autis mengontrol gerak motorik mereka.

Perkembangan teknologi informasi telah mempengaruhi bidang pendidikan, terutama pada proses pembelajaran dan isi materi. Pada tahap sekolah dasar, kecenderungan siswa lebih memilih permainan yang mengandung obyek 2 dimensi (2D) atau 3 dimensi (3D) dan mudah dimainkan. Pemberian materi pelajaran akan lebih mudah diterima apabila dirancang dalam sebuah permainan edukatif yang menarik, dan menyebabkan siswa menerima isi materi yang terdapat dalam permainan tidak langsung [5]. Penggunaan teknologi komputer untuk mendukung pendidikan dan terapi bagi anak-anak dengan disabilitas saat ini semakin gemar digunakan. Penggunaan program pendidikan berbasis multimedia yang menggabungkan fitur seperti gambar, grafis berwarna warni, suara berbentuk digital dan animasi pendukung membuat teknologi ini menarik bagi anak-anak autis [3]. Game edukasi, menggabungkan fitur-fitur animasi, warna-warna yang menarik, suara dalam setiap permainan yang tentu saja akan mengaktifkan gerak motorik anak selama bermain game.

Saat ini proses belajar mengajar di sekolah Rumah Pintar Salatiga umumnya masih menggunakan metode pembelajaran dengan beberapa media pembantu seperti buku dan alat peraga lainya serta terpusat pada guru. Contohnya, guru mengandalkan alat peraga gambar 2 dimensi (2D) dan buku untuk pembelajaran pengenalan obyek,. Metode ini disamping kurang menarik perhatian siswa ketika mengikuti pelajaran juga kurang melatih aktifitas gerak motorik mereka dalam rangka rehabilitasi. Salah satu cara untuk menyajikan pembelajaran yang menarik, penulis menggunakan kinect xbox 360 sebagai dasar pembuatan aplikasi game edukasi untuk anak autis tingkat sekolah dasar. Game edukasi dijalankan pada perangkat komputer. Banyak game edukasi berbasis Kinect untuk pembelajaran bagi anak autis. Salah satu teknologi sensor gerak yang cukup populer sebagai teknologi interaktif adalah kinect [6]. Game "Kinect Adventures" adalah beberapa contoh game berbasis kinect yang telah dibuat oleh International Journal of Innovative and Emerging Research in Engineering yang merupakan game edukasi berbasis kinect bagi anak autis. Tersedia beberapa mini-game olah raga dan lima macam game petualangan. Game ini dilengkapi beberapa contoh terkait dengan materi pendidikan dan fokus pada materi pembelajaran anak autis [4]. Aplikasi game edukasi yang berjudul "Game Edukasi Pengenalan Anggota Tubuh dan Pengenalan Angka Untuk Anak Berkebutuhan Khusus (ABK) Tunagrahita Berbasis Kinect”, yang fokusnya adalah pembelajaran pengenalan angka 1 sampai 5 dan pengenalan anggota tubuh bagian luar bagi anak tunagrahita [1]. Pada penelitian kali ini, penulis membuat aplikasi game bertema pengenalan anggota keluarga lingkup kecil (yang terdiri dari ibu, bapak, adik dan kakak), pengenalan objek di sekitar keluarga, dilengkapi dengan game berhitung ringan, mewarnai, memasang bentuk, menulis dan ayo bersikap baik bagi anak autis tingkat sekolah dasar.

\section{METODOLOGI PENELITIAN}

Observasi dan wawancara digunakan dalam penelitian ini, yaitu permasalahan yang terjadi pada kegiatan belajar mengajar bagi anak autis diinvestigasi serta mengidentifikasi penyelesaian yang dapat digunakan untuk menangani masalah tersebut. Berikut ini adalah hasil observasi dan wawancara terhadap guru pembimbing pada Sekolah Rumah Pintar ABK Salatiga:

a) Pembimbingan dan pendampingan dibutuhkan oleh siswa ketika menyerap materi pembelajaran.

b) Kebanyakan siswa autis kurang fokus pada materi yang disampaikan dan cepat merasa bosan. 
c) Kurikulum yang diajarkan berdasarkan kompetensi dari Pendidikan Nasional.

d) Dibutuhkan minimal dua guru sebagai pembimbing dan pendamping untuk satu kelas yang berisikan 10 hingga 12 siswa.

e) Salah satu metoda yang diterapkan pada Sekolah Rumah Pintar ABK Salatiga adalah bermain dengan mengenal gambar.

\subsection{Perancangan Aplikasi}

Perancangan aplikasi diawali dengan membuat storyboard yang berupa rangkaian sketsa visual untuk menggambarkan urutan atau alur dari game edukasi. Storyboard dari game edukasi pada penelitian ini ditunjukan pada gambar 1 . Terdiri dari 11 scene, yaitu dari scene 0 hingga scene 10, dengan penjelasan sebagai berikut :

a) Scene 0 : merupakan menu awal untuk memulai permainan

b) Scene 1 : merupakan menu utama

c) Scene 2 : merupakan scene pengenalan anggota keluarga

d) Scene 3 : merupakan menu belajar

e) Scene 4 : merupakan menu tulis dan warna

f) Scene 5-10: merupakan materi belajar huruf dan kata, warna, bangun, hitung, dan sikap
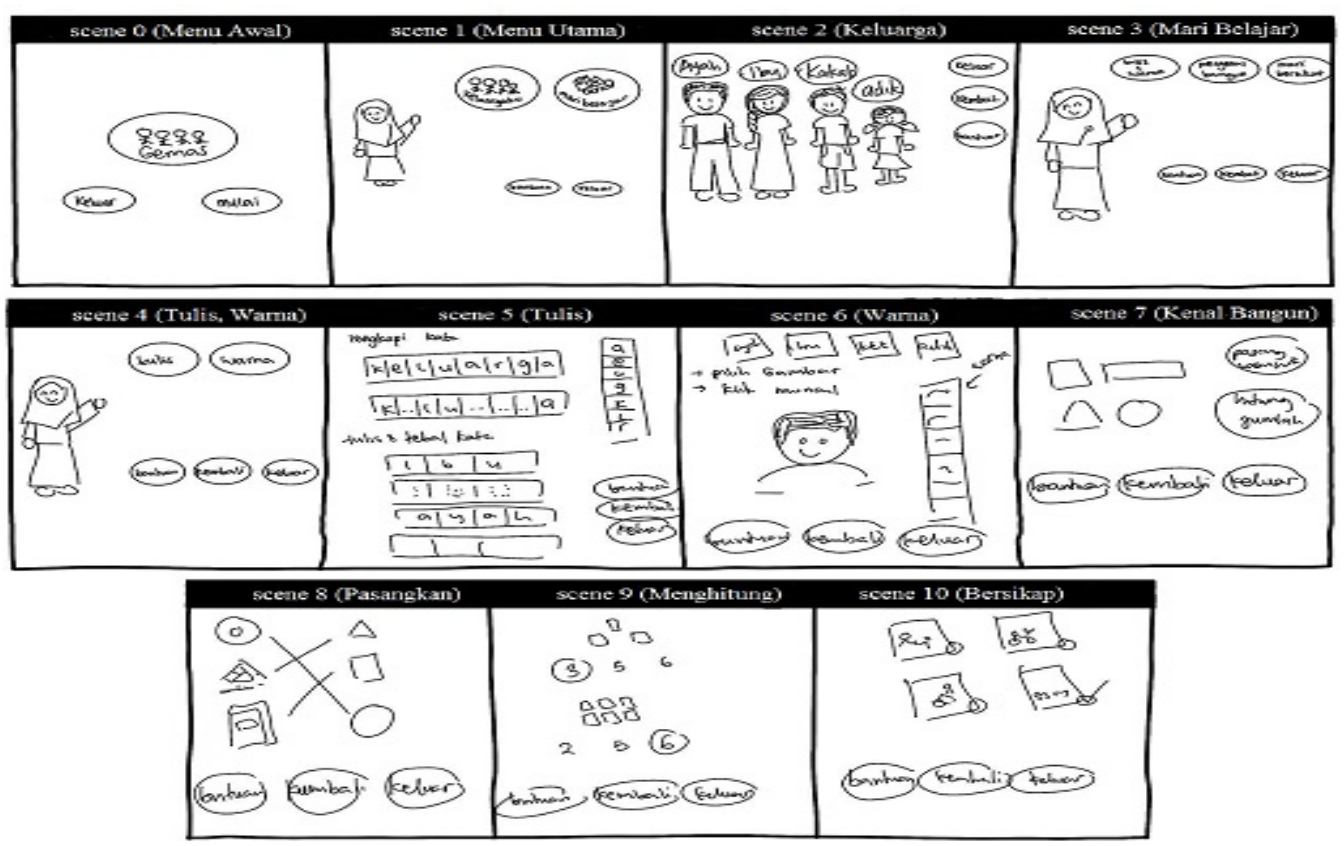

Gambar 1. Storyboard Game Edukasi Anak Autis

Tahap berikutnya adalah pembuatan aplikasi. Tahap ini dimulai dengan pembuatan asset menggunakan software Inkscape, yaitu pembuatan background, button dan karakter. Software Dragonbones digunakan untuk membuat animasi. Software utama yang digunakan untuk pembuatan aplikasi game ini adalah Unity 2D/3D serta Kinect SDK. Pengujian aplikasi dilakukan di Sekolah Rumah Pintar ABK Salatiga dengan melibatkan siswa-siswa autis tingkat sekolah dasar didampingi oleh guru pengajar. Data hasil kuisioner yang diisi oleh guru pengajar di Sekolah Rumah Pintar ABK Salatiga digunakan sebagai acuan untuk menganalisa aplikasi.

\section{HASIL DAN PEMBAHASAN}

Penelitian ini menghasilkan sebuah aplikasi game edukasi untuk anak autis berbasis Kinect xbox 360. Berikut pembahasan hasil dari penelitian game edukasi bagi anak autis bertema anggota keluarga berbasis kinect $x$ box360.

\subsection{Halaman Menu Awal Dan Menu Utama}

Sensor kinect harus terkoneksi terlebih dahulu dengan komputer yang digunakan sebelum memainkan game ini. Posisi pengguna adalah di depan sensor kinect kurang lebih 1,5 meter untuk 
memainkannya. Pengguna bisa mengendalikan kursor permainan dengan salah satu tangan sebagai controller dan sebagai ganti klik ketika menggunakan mouse, pengguna bisa menggenggamkan tangannya yang digunakan untuk main game. Pada awal permainan game ini akan muncul menu awal yang di dalamnya terdapat dua tombol pilihan, yaitu “mulai” dan”keluar”, seperti ditunjukkan pada gambar 2. Tombol "mulai” digunakan untuk memulai permainan dan tombol "keluar” digunakan untuk membatalkan permainan.

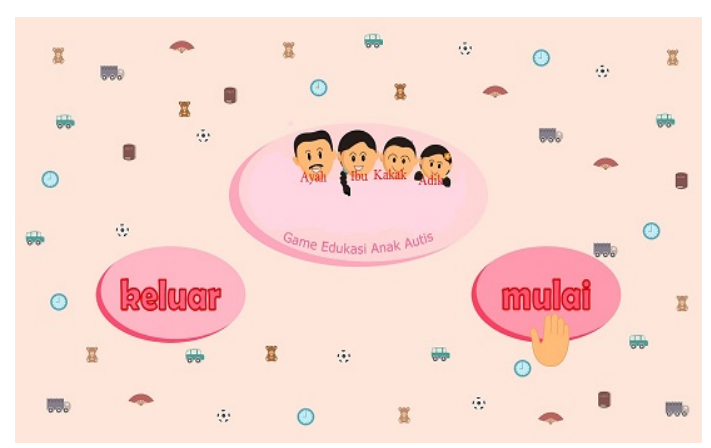

Gambar 2. Halaman Menu “Awal”

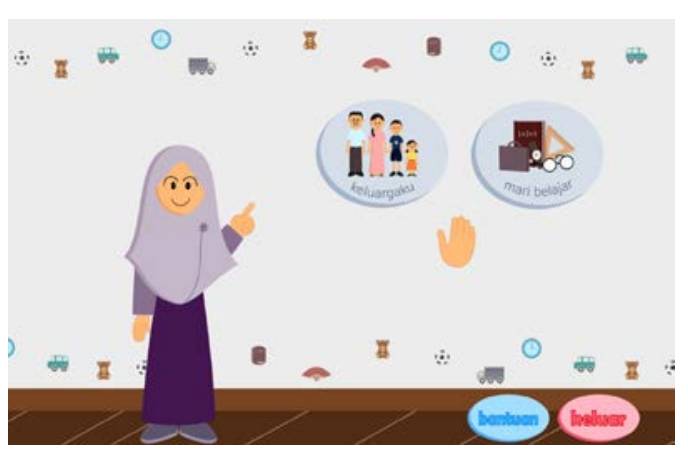

Gambar 3. Halaman Menu “Utama”

Gambar 3 merupakan tampilan menu utama. Tampilan ini akan muncul apabila tombol "mulai” pada menu awal dipilih. Terdapat dua pilihan menu permainan, yaitu "keluarga” dan "mari belajar”, selain itu tombol "bantuan” yang akan menunjukkan cara bermain pada setiap level, dan tombol "keluar” untuk meninggalkan permainan.

\subsection{Halaman Menu Keluarga}

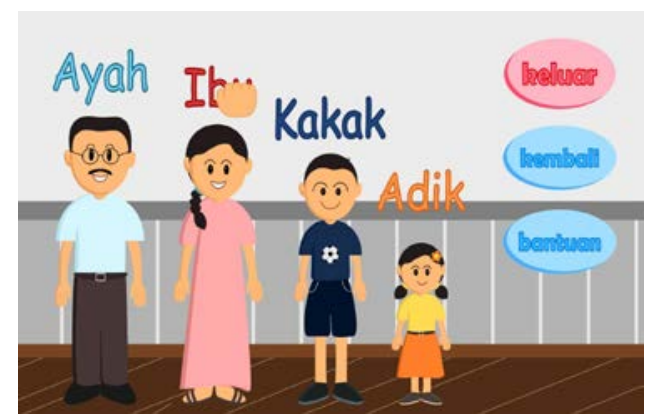

a

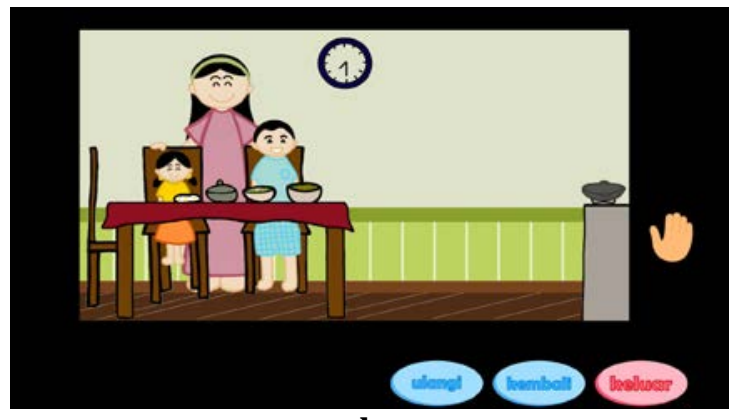

b

\section{Gambar 4. Halaman Menu “Keluarga”}

Gambar 4 adalah halaman menu "keluarga”. Terdapat empat menu yaitu “Ayah”, “Ibu”, “Kakak”, dan “Adik” seperti pada gambar 4a. Setiap menu yang dipilih akan menampilkan animasi dilengkapi audio yang berisi penjelasan sesuai dengan menu yang dipilih. Misalnya menu yang dipilih adalah "Ibu”, maka akan tampil animasi dan audio yang menjelaskan tentang sosok seorang ibu, tugas-tugas ibu seperti pada gambar $4 \mathrm{~b}$.

\subsection{Halaman Menu Mari Belajar}

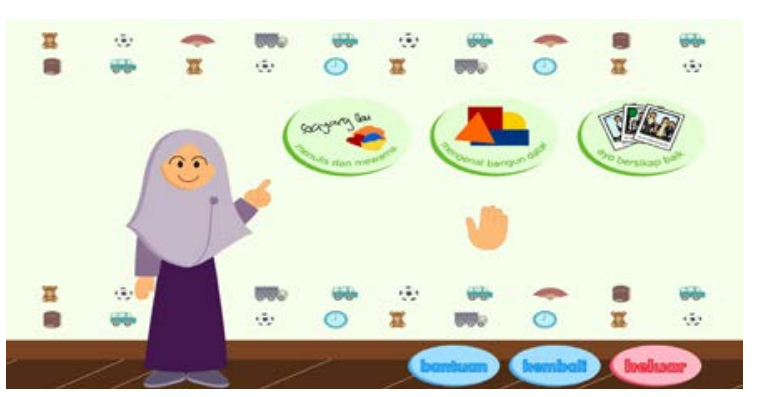

Gambar 5. Halaman Menu "Mari Belajar" 
Gambar 5 adalah halaman menu Mari Belajar. Halaman ini akan muncul ketika pengguna memilih tombol "mari belajar" pada menu utama. Pada halaman ini terdapat tiga menu yaitu "Ayo Bersikap Baik", "Mengenal Bangun Datar" dan "Menulis dan Mewarnai”. Setiap menu yang dipilih akan menampilkan permainan yang sesuai.

\subsection{Halaman Menu Menulis Dan Mewarnai}

Gambar 6 adalah halaman menu "Menulis dan Mewarnai”. Halaman ini akan tampil apabila tombol "Menulis dan Mewarnai” pada menu "Mari Belajar" dipilih oleh pengguna. Terdapat dua menu yaitu “Mari Menulis” dan "Mari Mewarnai”. Setiap menu yang dipilih akan menampilkan permainan yang sesuai.

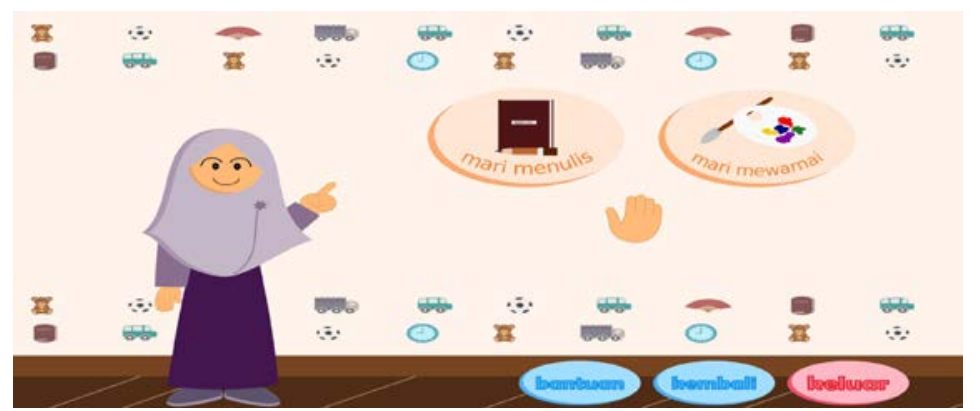

Gambar 6. Halaman Menu “Menulis Dan Mewarnai”

\subsubsection{Halaman Menu Menulis}

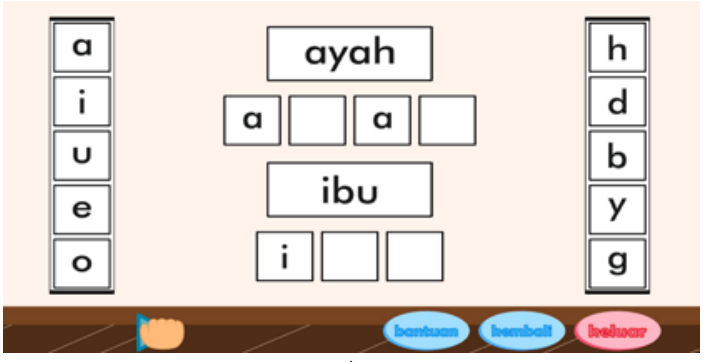

A

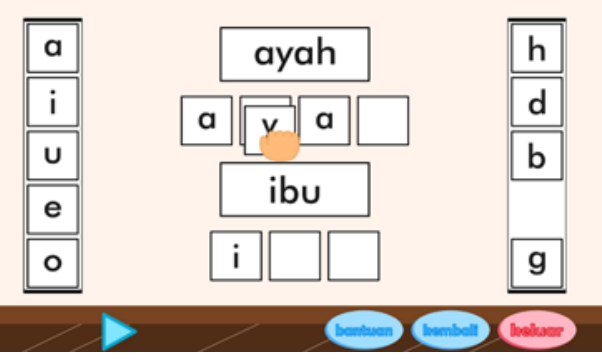

b

Gambar 7. Halaman Menu Menulis

Gambar 7 adalah salah satu contoh halaman permainan menulis. Halaman ini akan muncul apabila menu "menulis" pada halaman "Menulis dan Mewarnai" dipilih. Cara menulis pada permainan ini adalah pengguna tinggal memilih huruf yang sesuai yang telah disediakan pada kotak vertikal dengan menggerakkan tangannya di depan sensor kinect kemudian huruf yang dipilih diletakkan pada kotak kosong yang sesuai dengan cara drag and drop, seperti ditunjukkan pada gambar 7b. Pada permainan ini, terdapat lima soal dengan level yang semakin meningkat dilihat dari semakin banyaknya kotak yang kosong.

\subsubsection{Halaman Menu Mewarnai}

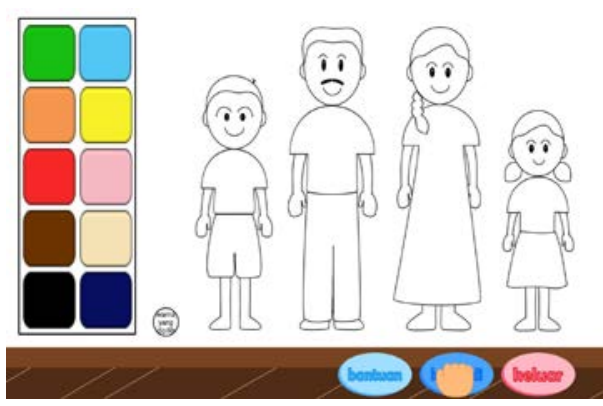

a

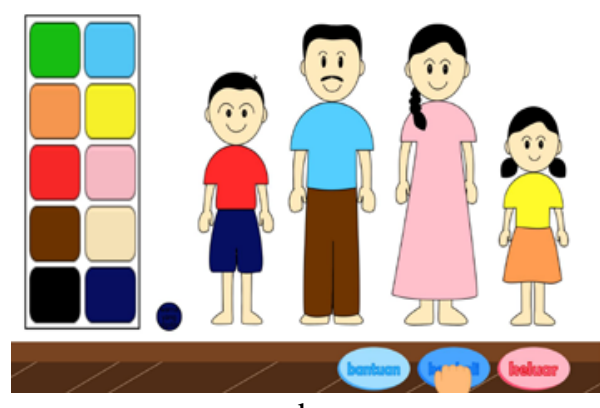

b

Gambar 8. Halaman Menu "Mewarnai” 
Gambar 8 adalah salah satu contoh halaman permainan dari menu "Mewarnai”. Cara memainkannya adalah dengan melakukan klik pada warna yang diinginkan lalu klik bagian obyek yang ingin diwarnai seperti yang terlihat pada Gambar 8b.

\subsection{Halaman Menu Mengenal Bangun Datar}

Gambar 9 adalah halaman menu “ Mengenal Bangun Datar”. Halaman ini akan muncul apabila menu "Mengenal Bangun Datar” pada halaman "Mari Belajar” dipilih. Terdapat empat buah gambar bangun datar. Setiap bangun datar yang di-klik akan muncul suara tentang nama bangun. Selain itu terdapat dua menu permainan yaitu "Menghitung Jumlah” dan “Memasangkan Bentuk”.

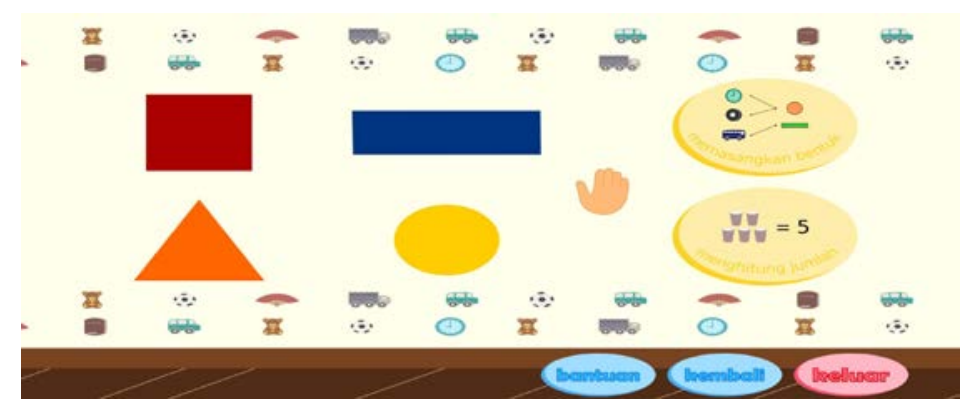

Gambar 9. Halaman Menu “Mengenal Bangun Datar”

\subsubsection{Halaman Menu Memasangkan Bentuk}

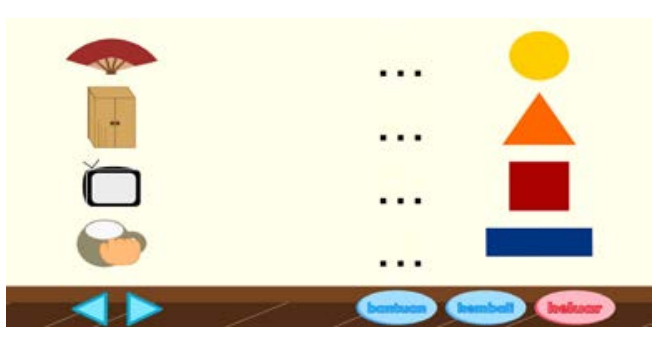

a

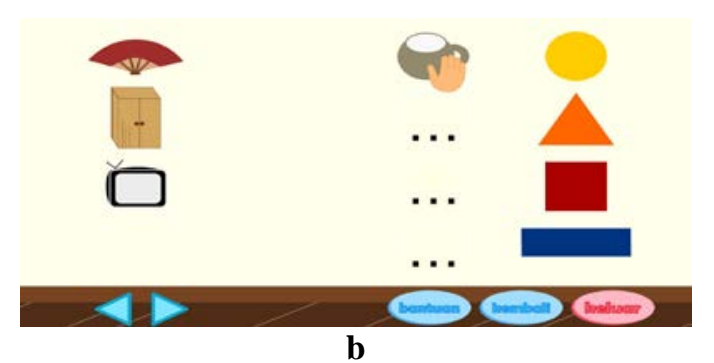

b

Gambar 10. Halaman Menu “Memasangkan Bentuk”

Gambar 10 adalah halaman permainan dari menu "Memasangkan Bentuk". Halaman ini akan muncul apabila menu "Memasangkan Bentuk” pada "Mengenal bangun Datar” dipilih. Terdapat berbagai macam pola permainan pada menu ini dengan level yang semakin meningkat. Cara memainkannya juga tidak sama, salah satunya adalah dengan menarik gambar obyek benda kemudian diletakkan pada tempat yang cocok dengan bentuk benda, sesuai seperti yang terlihat pada Gambar 10a dan 10b.

\subsubsection{Halaman Menu Menghitung Jumlah}
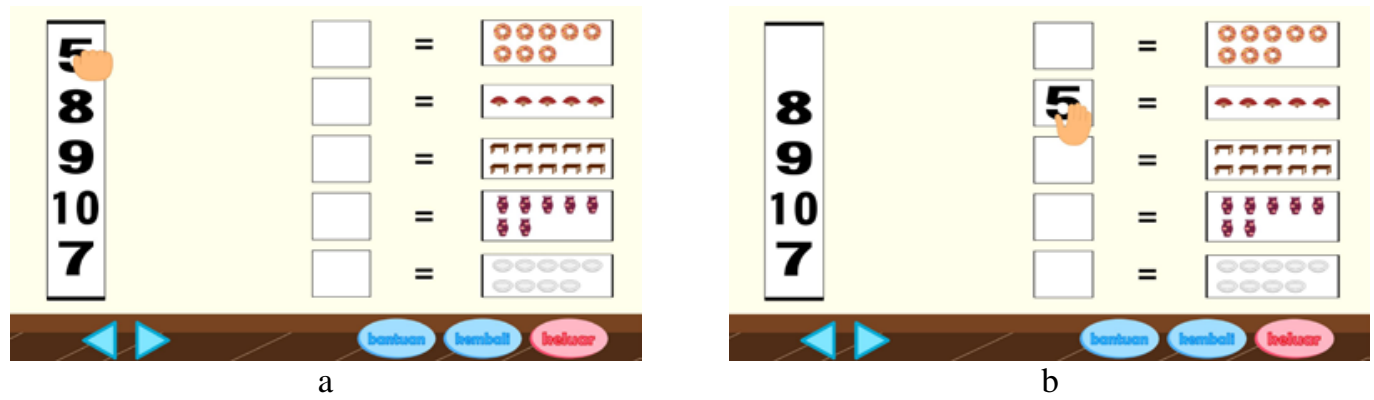

Gambar 11. Halaman Menu “Menghitung Jumlah”

Gambar 11 adalah halaman permainan menghitung jumlah. Halaman ini akan tampil apabila menu “Menghitung Jumlah” pada "Mengenal Bangun Datar” dipilih. Ada beberapa permainan dengan tingkat kesulitan yang semakin meningkat. Cara memainkannya adalah dengan menghitung jumlah benda pada 
soal lalu memilih angka yang sesuai dari kolom angka seperti ditunjukkan pada gambar 11a kemudian di drag dan di drop ke dalam kotak jawaban yang tersedia seperti terlihat pada 11b.

\subsection{Halaman Menu Ayo Bersikap Baik}

Gambar 12 adalah halaman permainan “ Ayo Bersikap Baik”. Terdapat tiga level permainan pada halaman ini. Cara memainkannya adalah pengguna tinggal memilih gambar mana yang menunjukkan sikap yang baik. Jika pilihannya betul maka akan terdapat tanda centang $(\sqrt{ })$ warna hijau dan suara "benar" seperti pada gambar 12a, namun bila pilihannya salah, maka akan terdapat tanda centang $(\sqrt{ })$ dan suara "salah" seperti pada gambar 12b. Perpindahan dari satu level ke level berikutnya dilakukan dengan menekan tombol lanjut ( ) pada setiap halaman permainan. Halaman permainan ini akan muncul apabila pengguna memilih menu "Ayo Bersikap Baik" pada halaman menu "Mari Belajar".

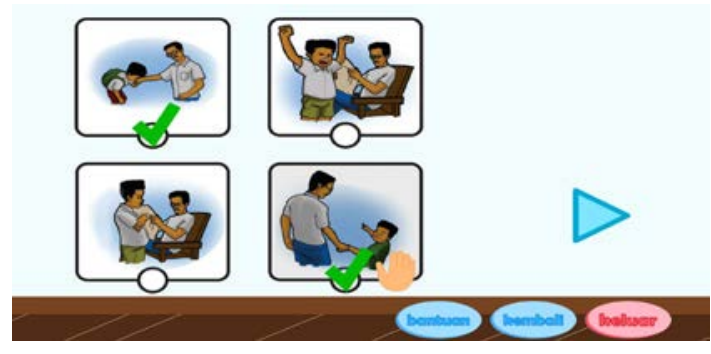

a

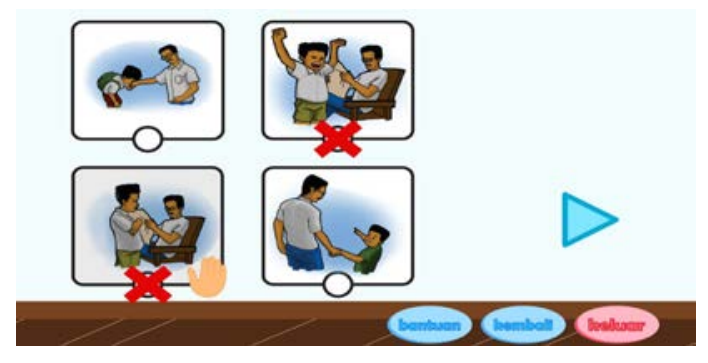

b

Gambar 12. Halaman Menu “Ayo Bersikap Baik”

\subsection{Hasil Pengujian Aplikasi}

Aplikasi game edukasi diuji di Sekolah Rumah Pintar (ABK) Salatiga, beberapa siswa tingkat sekolah dasar dengan didampingi oleh beberapa guru pembimbing dilibatkan dalam pengujian. Pengujian diawali dengan penulis mendemokan terlebih dahulu tentang aplikasi game edukasi pada guru-guru pembimbing dan para siswa. Selanjutnya penulis memberi kesempatan pada para siswa secara bergantian untuk memainkan game dengan cara menuntun mereka menggerakkan tangan perlahan-lahan menghadap sensor kinect. Setelah itu para siswa diberi kesempatan untuk memainkan game sendiri tanpa harus dituntun lagi. Penilaian terhadap aplikasi oleh guru pembimbing dilakukan melalui pengisian kuesioner setelah guru melihat proses setelah para siswa ketika memainkan game edukasi. Responden yang mengisi kuesioner adalah 15 orang. Terdapat 10 pernyataan dalam kuesioner sebagai berikut :

a) Game memiliki tampilan yang menarik.

b) Game yang dibuat bersifat interaktif

c) Game yang dibuat mudah dimainkan

d) Anak-anak sangat antusias dalam memainkan game ini

e) Game mampu menyebabkan anak tertarik belajar mengenal benda sekitar dan anggota keluarga

f) Materi dalam game sesuai dengan kurikulum pembelajaran

g) Materi pada game cukup untuk membantu anak belajar mengenal benda, bentuk dan anggota keluarga

h) Game yang dibuat dapat membantu guru memberikan variasi dalam menyampaikan materi mengenal benda, bentuk dan anggota keluarga

i) Secara keseluruhan game dapat digunakan sebagai sarana belajar dan bermain

j) Game memiliki audio yang terdengar

Berikut ini adalah hasil analisa kuesioner:

a) Tanggapan responden terhadap pernyataan 1 adalah 6 menyatakan sangat setuju (SS) dan 9 menyatakan setuju (S). Ini berarti bahwa game memiliki tampilan yang menarik.

b) Game bersifat interaktif. Ini berdasarkan tanggapan responden terhadap pernyataan 2, yaitu jumlah responden yang menyatakan sangat setuju (SS) yang menyatakan setuju (S) adalah sama, yaitu ada 7 orang, sedangkan 1 orang sisanya menyatakan netral $(\mathrm{N})$.

c) Game dinilai mudah dimainkan. Ini berdasarkan pernyataan responden yang sangat setuju (SS) dengan pernyataan 3 adalah 5 orang, sedangkan yang menyatakan setuju (S) adalah 9 orang dan sisanya 1 menyatakan netral $(\mathrm{N})$. 
d) Game dinilai dapat membuat anak-anak antusias. Ini berdasar pernyataan sangat setuju (SS) oleh 8 responden terhadap pernyataan 4, sedangkan 6 orang setuju (S), dan 1 orang menyatakan netral $(\mathrm{N})$,

e) Game dapat membuat anak tertarik untuk belajar mengenal anggota keluarga dan benda sekitar. Ini berdasarkan pernyataan 5 yang ditanggapi sangat setuju (SS) oleh 6 responden, 8 menyatakan setuju (S), dan 1 netral $(\mathrm{N})$.

f) Pernyataan sangat setuju (SS) oleh 8 responden sebagai tanggapan atas pernyataan 6, dan sisanya 7 orang menyatakan setuju (S). Ini mengandung pengertian bahwa materi game sudah sesuai dengan kurikulum Pendidikan Nasional (Diknas)..

g) Pernyataan 7 ditanggapi sangat setuju (SS) oleh 7 responden, 8 menanggapi setuju (S), sehingga materi pada game cukup membantu anak untuk belajar mengenal keluarga, bentuk, dan benda.

h) Game yang dibuat dapat membantu guru memberikan variasi dalam menyampaikan materi mengenal benda, bentuk dan anggota keluarga. Ini berdasarkan 6 responden yang menyatakan sangat setuju (SS) terhadap pernyataan 8 dan 9 orang menyatakan setuju (S).

i) Pernyataan 9 ditanggapi sangat setuju (SS) oleh 8 responden, dan 6 responden menyatakan setuju (S), sisanya 1 responden menyatakan netral (N). Berarti bahwa game Secara keseluruhan game dapat digunakan sebagai sarana belajar dan bermain bagi siswa autis.

j) Audio dalam game dinilai jelas didengar. Ini berdasar tanggapan responden terhadap pernyataan 10, yaitu 6 menyatakan sangat setuju (SS), 3 menyatakan setuju (S), dan 6 menyatakan netral (N).

\section{KESIMPULAN}

Kesimpulan yang dapat ditarik berdasarkan hasil penelitian adalah sebagai berikut :

a) Game edukasi yang dibuat menarik dan interaktif, sehingga dapat membantu meningkatkan antusiasme para siswa autis dalam belajar di sekolah Rumah Pintar Salatiga.

b) Game edukasi berbasis sensor kinect dapat menjadi salah satu alternatif baru untuk membimbing anak autis dalam mengenal benda, mengenal bentuk, dan mempelajari materi anggota keluarga.

c) Gerak motorik halus para siswa autis dapat direhabilitasi menggunakan aplikasi game edukasi, karena untuk memainkan game mereka harus menggerakkan tangan di depan sensor kinect sebagai game controller.

\section{DAFTAR PUSTAKA}

[1] Al Irsyadi, Fatah Yasin. dan Nugroho, Yusuf Sulistyo.,( 2015), “Game Edukasi Pengenalan Anggota Tubuh dan Pengenalan Angka Untuk Anak Berkebutuhan Khusus (ABK) Tunagrahita Berbasis Kinect”. Prosiding Seminar Nasional Teknologi Dan Informatika SNATIF Universitas Muria Kudus, 13-20.

[2] American Psychiatric Association. (2000). Diagnostic and statistical manual of mental disorders : $D S M-I V-T R$. Washington, DC.

[3] Bimantara, Afif., et al. 2015. "Implementasi Aplikasi Game Autisme “Ahada” Di SLB Bina Anggita Yogyakarta” Jurnal Ilmiah DASI STMIK AMIKOM Yogyakarta 16.2,1-11.

[4] Jaware, V.R., et al. 2016. "Kinect Technology for Children with Autism”. International Journal of Innovative and Emerging Research in Engineering, 68-72.

[5] Sudarmilah, Endah.,et al. 2013.” Tech Review: Game Platform for Upgrading Counting Ability on Preshool Children". Proceedings of 2013 International Conference on Information Technology and Electrical Engineering, 226-231.

[6] Yang, Y. H., et al. (2014), "The application of KINECT motion sensing technology in gameoriented study”. International Journal of Emerging Technologies in Learning, 59-63. 